\title{
Grape skin and seeds hardness assessment by texture analysis
}

\author{
Letaief, H., Rolle, L., Zeppa, G., Gerbi, V.
}

Department of Exploitation and Protection of the Agricultural and Forestry Resources - Microbiology and Food Technology sector - Turin University Via L. da Vinci 44 - 10095 Grugliasco (TO) - Italy.

Hind.1etaief@unito.it

\begin{abstract}
In order to optimize wine quality it is important to first characterize grape phenolic maturity and to determine the extractability of phenolic compounds during winemaking. The choice of harvest date is therefore very important but nevertheless still empirical. Previous works showed the interest of grape texture measurement as factor of grape maturity characterization. This work proposes to focus on berry skins and seed texture properties of three grapevine varieties: Cabernet sauvignon, Pinot noir and Nebbiolo from different growing areas and during two vintages, using a Universal Testing Machine TaxT2i Texture Analyzer. For the measurement of berry skin hardness, a needle probe was used, whereas for seed hardness a flat P/35 cylinder probe was used until a $50 \%$ deformation was reached. Tests were performed at $1 \mathrm{~mm} \cdot \mathrm{s}^{-1}$. Every test gave a force-deformation curve indicating the applied force at the skin and seed rupture point and the involved rupture energy.

The first part of the study concerned the validation of the method used for grape skin and seed hardness measurements. The second part was dedicated to the importance of grape skin and seed hardness for the varietal differentiation The collected data showed that since there is a significant difference between varieties, berry skin and seed hardness represents a meaningful parameter for varietal characterization and differentiation. In both years 2004 and 2005 , Nebbiolo was the variety with the toughest seeds $(55,8 \mathrm{~N}$ and $58,9 \mathrm{~N})$, but with the weakest berry skins $(0,46 \mathrm{~N}$ and $0,35 \mathrm{~N})$, in comparison to Pinot noir, which had the weakest seeds $(35,9 \mathrm{~N}$ and $41,3 \mathrm{~N})$ but the toughest berry skins $(0,57 \mathrm{~N}$ and $0,50 \mathrm{~N})$. Cabernet sauvignon showed a medium hardness for berry skins $(0,51 \mathrm{~N}$ and $0,46 \mathrm{~N})$ and seeds $(44,5 \mathrm{~N}$ and $43,4 \mathrm{~N})$.
\end{abstract}

Key words Grape, texture analysis, hardness

\section{Introduction}

The texture analysis is a surveying analytical technique for the definition and the control of food physical properties (Bourne, 2002). It is nowadays more and more applied in food sector because it is able to supply objective results. The first Texture Analysis studies on grape have been made on table varieties (Bernstein e Lustig, 1981). The assessment of pulp compactness and berry skin consistency is important for customer acceptance of the product (Sims e Halbrooks, 1986; Laszlo e Saayman, 1991; Mencarelli et al., 1994; Sato et al., 1997; Sato e Yamada, 2003).

There is little experience with Texture Analysis application on wine grapes. The scientific contributions are concerned principally with the study of some 
modifications concerning mechanical properties, like hardness evolution during ripening (Liang et al., 1990; Abbal et al., 1992; Robin et al., 1996; Robin et al.,1997; Rolle et al., 2006b; Ruiz Hernandez, 1996).

The knowledge of texture indices like berry skin thickness and hardness, as well as seed ripening degree, can present some fundamental qualitative information for the oenologist during the planning and management of pressing and maceration processes.

The assessment of technological maturity by sugar and acid measurements is not sufficient to completely predict the grapes oenological potentialities (Failla et al., 2005). Different studies aiming for the characterization of grape phenolic substances (Saint-Criq et al., 1998a,b; Moutounet et al., 1996; Cheynier, 2001; Borsa et al., 2002, Gerbi et al. 2003) and their evolution during the ripening (phenolic maturity) highlighted important grape quality indices (Glories e Augustin, 1993; Venencie et al., 1997; Saint-Criq et al., 1998c; Cayla et al., 2002; Crespy, 2002; Mattivi et al., 2002; Cagnasso et al., 2003).

Sensory analysis has also been favorably used to evaluate grape ripeness (Rousseau e Delteil, 2000; Rousseau, 2001; Martinez, 2002).

This work proposes to focus on berry skin and seed texture properties of three grapevine varieties: Cabernet sauvignon, Pinot noir and Nebbiolo from different growing areas and during two vintages.

\section{Materials and Methods}

\section{Sampling}

During the 2004 and 2005 vintages, Cabernet sauvignon, Pinot noir and Nebbiolo grapes from different vineyards in Piedmont (North West Italy) were analyzed .

At harvest, a randomised sample of 30 to 50 clusters of each variety was collected from each vineyard.

From each cluster sample, three sub-samples of 20 berries were taken randomly from three different positions: shoulder G1 (front and back), middle G2 (front and back) and bottom G3 of the cluster. See Figure1. The subsamples were taken without detaching the pedicel and all tests were performed the same day the berries were picked.
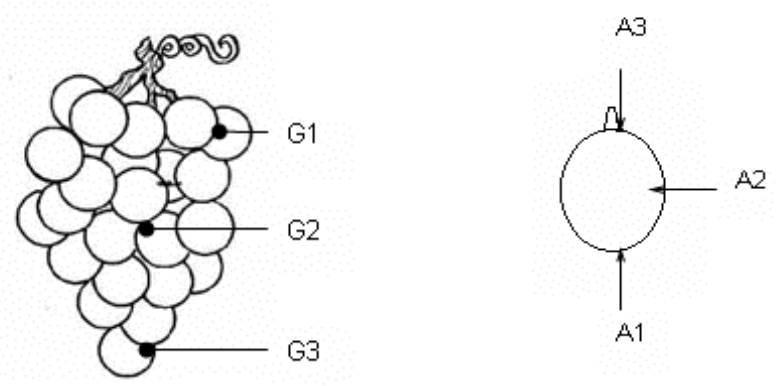

Figure1 On the left, berry sampling positions in the cluster (G1 shoulder, G2 middle, G3 bottom). On the right, berry skin puncture test positions (A1 top, A2 side, A3 bottom) 


\section{Analysis}

The analytical parameters of technological ripeness (\% Brix, total acidity, $\mathrm{pH})$ were estimated with official methodologies CE.

For the appraisal of grape mechanical properties, and for each individual berry, two different tests were made: berry skin and seeds hardness.

The measurements were made using a Universal Testing Machine TAxT2i Texture Analyzer (Stable Micro System, Godalming, Surrey, UK) equipped with a HDP/90 platform and a $25 \mathrm{Kg}$ load cell. The acquisitions were made at $400 \mathrm{~Hz}$, using Texture Expert Exceed software version 2.54 working in a Windows environment. The operative conditions applied for the tests' execution are resumed in Table1 (Uys, 1996; Grotte, 2001).

Table 1 Operational Parameters for the tests execution of the berry skin and seeds hardness

\begin{tabular}{lcccc}
\hline \multicolumn{1}{c}{ Test } & Probe & $\begin{array}{c}\text { Test } \\
\text { speed } \\
\left(\mathbf{m m s}^{-1}\right)\end{array}$ & Compression & Mechanical properties \\
\hline $\begin{array}{l}\text { Berry skin } \\
\text { hardness }\end{array}$ & Needle & 1 & $3 \mathrm{~mm}$ & $\begin{array}{l}\mathrm{F}_{\mathrm{sk}}=\text { berry skin break Force }(\mathrm{N}) \\
\mathrm{W}_{\mathrm{sk}}=\text { berry skin break Energy }(\mathrm{mJ})\end{array}$ \\
\hline $\begin{array}{l}\text { Seed } \\
\text { hardness }\end{array}$ & $\varnothing 35 \mathrm{~mm}$ & 1 & $50 \%$ & $\begin{array}{l}\mathrm{F}_{\mathrm{s}}=\text { seed break Force }(\mathrm{N}) \\
\mathrm{W}_{\mathrm{s}}=\text { seed break Energy }(\mathrm{mJ})\end{array}$ \\
\hline
\end{tabular}

\section{Preliminary beery skin hardness test}

In previous works on table and wine grapes, the berries used for the berry skin analysis were placed on the horizontal metal plate of the Texture analyzer with the pedicel in a horizontal plane (Lee and Bourne, 1980; Rolle et al., 2006a,b).

This preliminary berry skin hardness test was carried out on Cabernet sauvignon and Pinot noir sub-samples from the 2005 harvest, in order to compare three puncture positions on the berry (top, side and bottom), and find out which of these positions leads to the most reproducible results. See Figure1.

\section{Statistical analysis}

The data elaboration was made using the Statistica Software version 7.0 (StatSoft Inc., Tulsa, OK, USA).

\section{Results and discussions}

Table2 reports the technological ripeness parameters of Cabernet sauvignon, Pinot noir and Nebbiolo at the two harvest seasons 2004 and 2005.

Table2 Technological ripeness of Cabernet sauvignon, Pinot noir and Nebbiolo grapes at harvest seasons of 2004 and 2005 . The data is the mean of vineyards

\begin{tabular}{lcccccc}
\hline & \multicolumn{3}{c}{2004} & \multicolumn{2}{c}{2005} \\
\cline { 2 - 6 } & $\begin{array}{c}\text { Brix } \\
\%\end{array}$ & $\begin{array}{c}\text { Total acidity } \\
\text { (g/L tartaric } \\
\text { acid) }\end{array}$ & $\mathrm{pH}$ & $\begin{array}{c}\text { Brix } \\
\%\end{array}$ & $\begin{array}{c}\text { Total acidity } \\
(\mathrm{g} / \text { L tartaric acid) }\end{array}$ & $\mathrm{pH}$ \\
\hline Cabernet sauvignon & 23,8 & 5,7 & 3,12 & 22,4 & 7,5 & 3,18 \\
Pinot noir & 20,3 & 7,6 & 3,08 & 21,0 & 9,9 & 3,03 \\
Nebbiolo & 23,8 & 7,0 & 3,10 & 24,6 & 6,7 & 3,12 \\
\hline
\end{tabular}


Figure 2 shows a typical Force-time (or deformation) curve obtained with the berry skin puncture test. The berry skin hardness is assessed either by the maximum break force (Fsk) or by the break energy $\left(\mathrm{W}_{\mathrm{sk}}\right)$. The first parameter corresponds to the skin resistance to the probe penetration while the second parameter is represented by the area under the curve, which is limited between the 0 point and $\mathrm{F}_{\text {sk }}$.

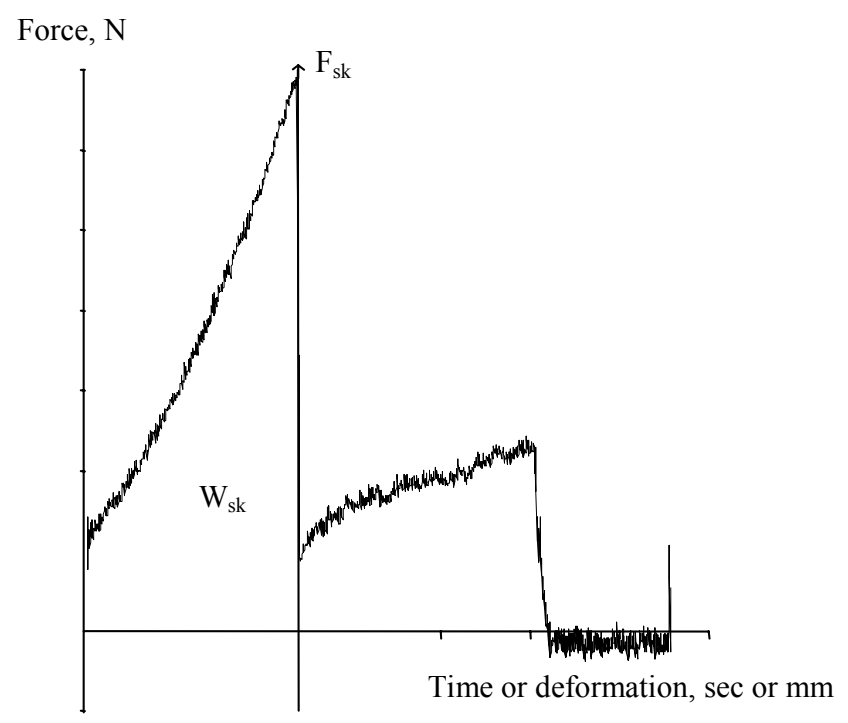

Figure2 Force-time (deformation) curve corresponding to the berry skin puncture test

The Force-time curve, related to the seed hardness test, is reported in Figure 3. Break Force (Fs) corresponds to the first peak, while break energy $\left(\mathrm{W}_{\mathrm{s}}\right)$ corresponds to the area under the curve which is limited by the 0 point and the break point. D1 represents the break distance. $E_{s}$ is a measure of the material's resistance to axial deformation. It represents the stiffness of the material to an applied load. The larger the stiffness, the higher the force or stress needed to cause a given deformation or strain. Its value is calculated as the slope of the stress-strain curve in the linear section (Vargas et al., 2001).

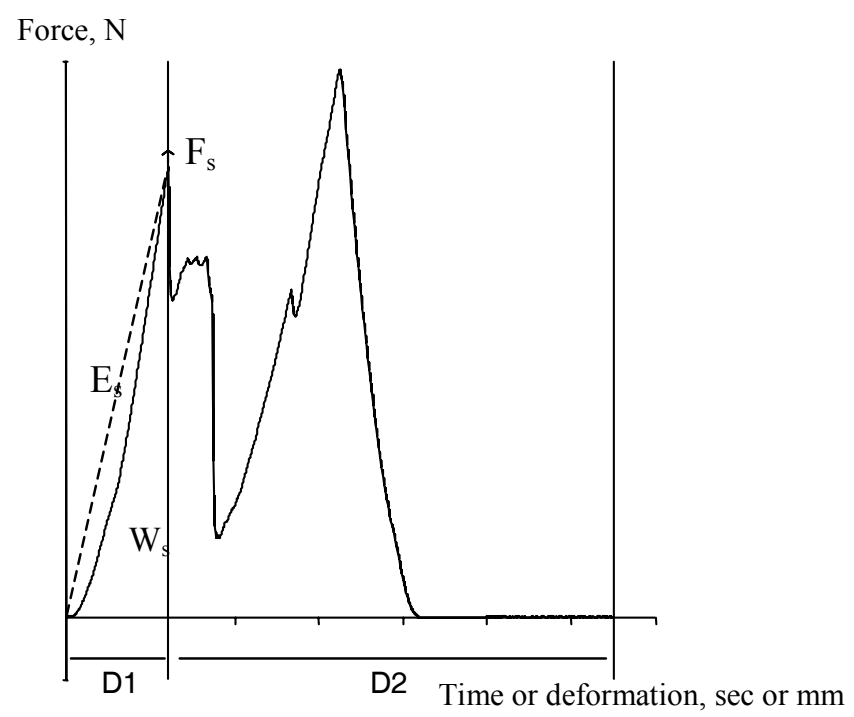

Figure3 Force-distance curve related to the test for seed hardness determination 
The results of the preliminary berry skin hardness tests are reported in Table3. Results show a significant difference between the three puncture positions (A1, A2, A3) whereas there is no significant difference between the berries picked from different positions of the cluster, as shown in Table4. It is therefore possible to underline that the berry skin hardness test is not affected by the sub-sampling position because whether the berries are picked in the top, the middle or the bottom of the cluster, they still have the same skin mechanical properties. In contrast, the test is affected by the positioning of the berry on the horizontal metal plate of the Texture Analyzer: with the pedicel in horizontal (A2) or vertical plane (A1 and A3).

The differences according to the berry puncture position between the two vineyards of Cabernet sauvignon and Pinot noir are shown in Table 5 and Table6. For Cabernet sauvignon, there is no significant difference between the vineyards if the puncture test is carried out in A1 or A2 points, whereas the difference is significant $(p<0,05)$ when the puncture point is A3. The same comparison between Pinot noir vineyards showed that there is a significant difference if the test is made in A2 and A3 points $(p<0,001)$ while there is no significant difference if the puncture position is A1. The results given by A2 are therefore more reproducible than A1 and A3 and consequently, it is considered the best position for the puncture test and supports the methods of Lee and Bourne (1980) and Rolle et al. (2006a,b) for grape puncture tests.

Table3 Berry skin hardness parameters of Cabernet sauvignon and Pinot noir measured in different puncture positions. Sign $=$ significance; $* * * \mathbf{p}<0.001, * * p<0.01$, $* \mathbf{p}<0.05, \mathrm{~ns}=$ not significant

\begin{tabular}{|c|c|c|c|c|c|c|c|c|c|}
\hline & \multicolumn{4}{|c|}{ Fsk (N) } & \multicolumn{4}{|c|}{ Wsk $(\mathrm{mJ})$} \\
\hline & & A1 & A2 & A3 & Sign & A1 & A2 & A3 & Sign \\
\hline \multirow{3}{*}{$\begin{array}{c}\text { Cabernet } \\
\text { sauvignon } 1\end{array}$} & G 1 & $\begin{array}{c}0,39^{b} \pm \\
0.09\end{array}$ & $\begin{array}{c}0,41^{\mathrm{b}} \pm \\
0.09\end{array}$ & $\begin{array}{c}0,29^{\mathrm{a}} \pm \\
0.04\end{array}$ & *: & $\begin{array}{c}0,19^{b} \pm \\
0.09\end{array}$ & $\begin{array}{c}0,22^{\mathrm{b}} \pm \\
0.08\end{array}$ & $\begin{array}{c}0,10^{\mathrm{a}} \pm \\
0.03\end{array}$ & $* * *$ \\
\hline & G2 & $\begin{array}{c}0,36^{b} \pm \\
0,06\end{array}$ & $\begin{array}{c}0,42^{\mathrm{c}} \pm \\
0,08\end{array}$ & $\begin{array}{c}0,29^{\mathrm{a}} \pm \\
0,06\end{array}$ & $* * *$ & $\begin{array}{c}0,18^{\mathrm{b}} \pm \\
0,05\end{array}$ & $\begin{array}{c}0,22^{\mathrm{b}} \pm \\
0,08\end{array}$ & $\begin{array}{c}0,11^{\mathrm{a}} \pm \\
0,05\end{array}$ & $* * *$ \\
\hline & G3 & $\begin{array}{c}0,38^{\mathrm{b}} \pm \\
0,07\end{array}$ & $\begin{array}{c}0,43^{\mathrm{b}} \pm \\
0,06\end{array}$ & $\begin{array}{c}0,29^{\mathrm{a}} \pm \\
0,06\end{array}$ & $* * *$ & $\begin{array}{c}0,19^{\mathrm{b}} \pm \\
0,06\end{array}$ & $\begin{array}{c}0,24^{\mathrm{b}} \pm \\
0,06\end{array}$ & $\begin{array}{c}0,12^{\mathrm{a}} \pm \\
0,06\end{array}$ & $* * *$ \\
\hline \multirow{3}{*}{$\begin{array}{c}\text { Cabernet } \\
\text { sauvignon } 2\end{array}$} & G1 & $\begin{array}{c}0,36^{b} \pm \\
0,055\end{array}$ & $\begin{array}{c}0,44^{\mathrm{c}} \pm \\
0,06\end{array}$ & $\begin{array}{c}0,29^{\mathrm{a}} \pm \\
0,05\end{array}$ & $* * *$ & $\begin{array}{c}0,19^{\mathrm{b}} \pm \\
0,07\end{array}$ & $\begin{array}{c}0,25^{\mathrm{c}} \pm \\
0,06\end{array}$ & $\begin{array}{c}0,11^{\mathrm{a}} \pm \\
0,04\end{array}$ & $* * *$ \\
\hline & G2 & $\begin{array}{c}0,37^{\mathrm{b}} \pm \\
0,08\end{array}$ & $\begin{array}{c}0,41^{\mathrm{b}} \pm \\
0,06\end{array}$ & $\begin{array}{c}0,26^{\mathrm{a}} \pm \\
0,05\end{array}$ & & $\begin{array}{c}0,18^{\mathrm{b}} \pm \\
0,06\end{array}$ & $\begin{array}{c}0,23^{\mathrm{c}} \pm \\
0,06\end{array}$ & $\begin{array}{c}0,09^{\mathrm{a}} \pm \\
0,03\end{array}$ & $* * *$ \\
\hline & G3 & $\begin{array}{c}0,36^{\mathrm{b}} \pm \\
0,06\end{array}$ & $\begin{array}{c}0,41^{\mathrm{b}} \pm \\
0,05\end{array}$ & $\begin{array}{c}0,26^{\mathrm{a}} \pm \\
0,05\end{array}$ & $* * *$ & $\begin{array}{c}0,18^{\mathrm{b}} \pm \\
0,06\end{array}$ & $\begin{array}{c}0,22^{\mathrm{b}} \pm \\
0,05\end{array}$ & $\begin{array}{c}0,09^{\mathrm{a}} \pm \\
0,03\end{array}$ & $* * *$ \\
\hline \multirow{3}{*}{ Pinot noir 1} & G1 & $\begin{array}{c}0,39^{\mathrm{a}} \pm \\
0,10\end{array}$ & $\begin{array}{c}0,53^{\mathrm{b}} \pm \\
0,08^{\circ}\end{array}$ & $\begin{array}{c}0,41^{\mathrm{b}} \pm \\
0,06\end{array}$ & & $\begin{array}{c}0,19^{\mathrm{a}} \\
0,08\end{array}$ & $\begin{array}{c}0,31^{b} \pm \\
0,07\end{array}$ & $\begin{array}{c}0,18^{\mathrm{a}} \pm \\
0,04\end{array}$ & $* * *$ \\
\hline & G2 & $\begin{array}{c}0,43^{\mathrm{b}} \pm \\
0,08\end{array}$ & $\begin{array}{c}0,57^{\mathrm{c}} \pm \\
0,05\end{array}$ & $\begin{array}{c}0,38^{\mathrm{a}} \pm \\
0,05\end{array}$ & $* * *$ & $\begin{array}{c}0,22^{\mathrm{b}} \pm \\
0,07\end{array}$ & $\begin{array}{c}0,31^{\mathrm{c}} \pm \\
0,05\end{array}$ & $\begin{array}{c}0,19^{\mathrm{a}} \pm \\
0,06\end{array}$ & $* * *$ \\
\hline & G3 & $\begin{array}{c}0,42^{\mathrm{b}} \pm \\
0,07\end{array}$ & $\begin{array}{c}0,56^{\mathrm{c}} \pm \\
0,08\end{array}$ & $\begin{array}{c}0,35^{\mathrm{a}} \pm \\
0,07\end{array}$ & $* * *$ & $\begin{array}{c}0,22^{\mathrm{b}} \pm \\
0,06\end{array}$ & $\begin{array}{c}0,29^{\mathrm{c}} \pm \\
0,08\end{array}$ & $\begin{array}{c}0,19^{\mathrm{a}} \pm \\
0,06\end{array}$ & $* * *$ \\
\hline \multirow{3}{*}{ Pinot noir 2} & G1 & $\begin{array}{c}0,41^{\mathrm{b}} \pm \\
0,10\end{array}$ & $\begin{array}{c}0,46^{\mathrm{b}} \pm \\
0,06\end{array}$ & $\begin{array}{c}0,35^{\mathrm{a}} \pm \\
0,06\end{array}$ & $*$ & $\begin{array}{c}0,19^{\mathrm{a}} \pm \\
0,08\end{array}$ & $\begin{array}{c}0,26^{\mathrm{b}} \pm \\
0,05\end{array}$ & $\begin{array}{c}0,16^{\mathrm{a}} \pm \\
0,05\end{array}$ & $* * *$ \\
\hline & G2 & $\begin{array}{c}0,40^{\mathrm{a}} \pm \\
0,11\end{array}$ & $\begin{array}{c}0,50^{\mathrm{b}} \pm \\
0,09\end{array}$ & $\begin{array}{c}0,35^{\mathrm{a}} \pm \\
0,05\end{array}$ & $* * *$ & $\begin{array}{c}0,20^{\mathrm{a}} \pm \\
0,09\end{array}$ & $\begin{array}{c}0,30^{\mathrm{b}} \pm \\
0,06\end{array}$ & $\begin{array}{c}0,16^{\mathrm{a}} \pm \\
0,05\end{array}$ & $* * *$ \\
\hline & G3 & $\begin{array}{c}0,43^{\mathrm{b}} \pm \\
0,11\end{array}$ & $\begin{array}{c}0,48^{\mathrm{b}} \pm \\
0,08\end{array}$ & $\begin{array}{c}0,35^{\mathrm{a}} \pm \\
0,04\end{array}$ & $* * *$ & $\begin{array}{c}0,24^{\mathrm{b}} \pm \\
0,10\end{array}$ & $\begin{array}{c}0,27^{\mathrm{b}} \pm \\
0,08\end{array}$ & $\begin{array}{c}0,16^{\mathrm{a}} \pm \\
0,04\end{array}$ & $* * *$ \\
\hline
\end{tabular}


Table4 Berry skin hardness parameters of Cabernet sauvignon and Pinot noir sampled from different positions in the cluster. Sign = significance; $* * * p<0.001, * * p<0.01$, $*$ p $<0.05$, ns $=$ not significant

\begin{tabular}{|c|c|c|c|c|c|c|c|c|c|}
\hline & \multicolumn{4}{|c|}{ Fsk (N) } & \multicolumn{4}{|c|}{ Wsk $(\mathrm{mJ})$} \\
\hline & & G1 & G2 & G3 & Sign & G1 & G2 & G3 & Sign \\
\hline \multirow{3}{*}{$\begin{array}{c}\text { Cabernet } \\
\text { sauvignon } 1\end{array}$} & A 1 & $\begin{array}{c}0,39 \pm \\
0,09\end{array}$ & $\begin{array}{c}0,37 \pm \\
0,06\end{array}$ & $\begin{array}{c}0,39 \pm \\
0,07\end{array}$ & $\mathrm{~ns}$ & $\begin{array}{c}0,19 \pm \\
0,09\end{array}$ & $\begin{array}{c}0,18 \pm \\
0,05\end{array}$ & $\begin{array}{c}0,19 \pm \\
0,06\end{array}$ & $\mathrm{~ns}$ \\
\hline & A2 & $\begin{array}{c}0,42 \pm \\
0,09\end{array}$ & $\begin{array}{c}0,42 \pm \\
0,08\end{array}$ & $\begin{array}{c}0,43 \pm \\
0,06\end{array}$ & $\mathrm{~ns}$ & $\begin{array}{c}0,22^{\mathrm{b}} \pm \\
0,08\end{array}$ & $\begin{array}{c}0,22 \pm \\
0,08\end{array}$ & $\begin{array}{c}0,24 \pm \\
0,06\end{array}$ & $\mathrm{~ns}$ \\
\hline & A 3 & $\begin{array}{c}0,29 \pm \\
0,04\end{array}$ & $\begin{array}{c}0,29 \pm \\
0,06\end{array}$ & $\begin{array}{c}0,29 \pm \\
0,06\end{array}$ & $\mathrm{~ns}$ & $\begin{array}{c}0,10 \pm \\
0,03\end{array}$ & $\begin{array}{c}0,11 \pm \\
0,05\end{array}$ & $\begin{array}{c}0,12 \pm \\
0,06\end{array}$ & $\mathrm{~ns}$ \\
\hline \multirow{3}{*}{$\begin{array}{c}\text { Cabernet } \\
\text { sauvignon } 2\end{array}$} & A 1 & $\begin{array}{c}0,37 \pm \\
0,05\end{array}$ & $\begin{array}{c}0,37 \pm \\
0,08\end{array}$ & $\begin{array}{c}0,37 \pm \\
0,06\end{array}$ & $\mathrm{~ns}$ & $\begin{array}{c}0,19 \pm \\
0,07\end{array}$ & $\begin{array}{c}0,18 \pm \\
0,06\end{array}$ & $\begin{array}{c}0,18 \pm \\
0,06\end{array}$ & $\mathrm{~ns}$ \\
\hline & A2 & $\begin{array}{c}0,44 \pm \\
0,06\end{array}$ & $\begin{array}{c}0,41 \pm \\
0,06\end{array}$ & $\begin{array}{c}0,41 \pm \\
0,05\end{array}$ & $\mathrm{~ns}$ & $\begin{array}{c}0,25 \pm \\
0,06\end{array}$ & $\begin{array}{c}0,23 \pm \\
0,06\end{array}$ & $\begin{array}{c}0,22 \pm \\
0,05\end{array}$ & $\mathrm{~ns}$ \\
\hline & A 3 & $\begin{array}{c}0,29^{\mathrm{b}} \pm \\
0,05\end{array}$ & $\begin{array}{l}0,26^{\mathrm{a}, \mathrm{b}} \\
\pm 0,06\end{array}$ & $\begin{array}{c}0,26^{\mathrm{a}} \pm \\
0,05\end{array}$ & $*$ & $\begin{array}{c}0,11 \pm \\
0,04\end{array}$ & $\begin{array}{c}0,09 \pm \\
0,03\end{array}$ & $\begin{array}{c}0,09 \pm \\
0,03\end{array}$ & $\mathrm{~ns}$ \\
\hline \multirow{3}{*}{ Pinot noir 1} & A 1 & $\begin{array}{c}0,38 \pm \\
0,10\end{array}$ & $\begin{array}{c}0,44 \pm \\
0,08\end{array}$ & $\begin{array}{c}0,43 \pm \\
0,07\end{array}$ & $\mathrm{~ns}$ & $\begin{array}{c}0,19 \pm \\
0,08\end{array}$ & $\begin{array}{c}0,22 \pm \\
0,07\end{array}$ & $\begin{array}{c}0,22 \pm \\
0,06\end{array}$ & $\mathrm{~ns}$ \\
\hline & A2 & $\begin{array}{c}0,53 \pm \\
0,08\end{array}$ & $\begin{array}{c}0,57 \pm \\
0,05\end{array}$ & $\begin{array}{c}0,56 \pm \\
0,08\end{array}$ & $\mathrm{~ns}$ & $\begin{array}{c}0,31 \pm \\
0,07\end{array}$ & $\begin{array}{c}0,31 \pm \\
0,05\end{array}$ & $\begin{array}{c}0,29 \pm \\
0,08\end{array}$ & $\mathrm{~ns}$ \\
\hline & A3 & $\begin{array}{c}0,42^{\mathrm{b}} \pm \\
0,06\end{array}$ & $\begin{array}{l}0,38^{\mathrm{a}, \mathrm{b}} \\
\pm 0,05\end{array}$ & $\begin{array}{c}0,35^{\mathrm{a}} \pm \\
0,07\end{array}$ & $* *$ & $\begin{array}{c}0,18 \pm \\
0,04\end{array}$ & $\begin{array}{c}0,19 \pm \\
0,06\end{array}$ & $\begin{array}{c}0,19 \pm \\
0,06\end{array}$ & $\mathrm{~ns}$ \\
\hline \multirow{3}{*}{ Pinot noir 2} & A 1 & $\begin{array}{c}0,42 \pm \\
0,10\end{array}$ & $\begin{array}{c}0,40 \pm \\
0,11\end{array}$ & $\begin{array}{c}0,43 \pm \\
0,11\end{array}$ & $\mathrm{~ns}$ & $\begin{array}{c}0,19 \pm \\
0,08\end{array}$ & $\begin{array}{c}0,20 \pm \\
0,09\end{array}$ & $\begin{array}{c}0,24 \pm \\
0,10\end{array}$ & $\mathrm{~ns}$ \\
\hline & A2 & $\begin{array}{c}0,46 \pm \\
0,06\end{array}$ & $\begin{array}{c}0,50 \pm \\
0,09\end{array}$ & $\begin{array}{c}0,48 \pm \\
0,08\end{array}$ & $\mathrm{~ns}$ & $\begin{array}{c}0,26 \pm \\
0,05\end{array}$ & $\begin{array}{c}0,30 \pm \\
0,06\end{array}$ & $\begin{array}{c}0,27 \pm \\
0,08\end{array}$ & $\mathrm{~ns}$ \\
\hline & A 3 & $\begin{array}{c}0,35 \pm \\
0,06\end{array}$ & $\begin{array}{c}0,35 \pm \\
0,05\end{array}$ & $\begin{array}{c}0,35 \pm \\
0,04\end{array}$ & $\mathrm{~ns}$ & $\begin{array}{c}0,16 \pm \\
0,05\end{array}$ & $\begin{array}{c}0,16 \pm \\
0,05\end{array}$ & $\begin{array}{c}0,16 \pm \\
0,04\end{array}$ & $\mathrm{~ns}$ \\
\hline
\end{tabular}

Table5 Berry skin hardness of two Cabernet sauvignon vineyards. Sign = significance; $* * * \mathbf{p}<0.001, * * \mathbf{p}<0.01, * \mathbf{p}<0.05$, ns $=$ not significant.

\begin{tabular}{ccccccc}
\hline & \multicolumn{3}{c}{ Fsk $(\mathrm{N})$} & \multicolumn{3}{c}{ Wsk $(\mathrm{mJ})$} \\
\cline { 2 - 7 } & $\begin{array}{c}\text { Cabernet } \\
\text { sauvignon 1 }\end{array}$ & $\begin{array}{c}\text { Cabernet } \\
\text { sauvignon 2 }\end{array}$ & Sign & $\begin{array}{c}\text { Cabernet } \\
\text { sauvignon 1 }\end{array}$ & $\begin{array}{c}\text { Cabernet } \\
\text { sauvignon 2 }\end{array}$ & Sign \\
\hline A1 & $0,38 \pm 0,07$ & $0,37 \pm 0,06$ & ns & $0,19 \pm 0,07$ & $0,18 \pm 0,06$ & ns \\
A2 & $0,42 \pm 0,08$ & $0,42 \pm 0,06$ & ns & $0,23 \pm 0,08$ & $0,23 \pm 0,06$ & ns \\
A3 & $0,29 \pm 0,06$ & $0,27 \pm 0,05$ & $*$ & $0,11 \pm 0,05$ & $0,10 \pm 0,04$ & ns \\
\hline
\end{tabular}

Table6 Berry skin hardness of two Pinot noir vineyards. Sign = significance; ***p< $0.001, * * p<0.01, * p<0.05$, ns $=$ not significant.

\begin{tabular}{ccccccc}
\hline & \multicolumn{4}{c}{ Fsk $(\mathrm{N})$} \\
\cline { 2 - 7 } & Pinot noir 1 & Pinot noir 2 & Sign & Pinot noir 1 & Pinot noir 2 & Sign \\
\hline A1 & $0,42 \pm 0,09$ & $0,42 \pm 0,11$ & ns & $0,21 \pm 0,07$ & $0,21 \pm 0,09$ & ns \\
A2 & $0,55 \pm 0,07$ & $0,48 \pm, 076$ & $* * *$ & $0,30 \pm 0,07$ & $0,28 \pm, 064$ & $*$ \\
A3 & $0,38 \pm 0,06$ & $0,35 \pm 0,05$ & $* * *$ & $0,17 \pm 0,05$ & $0,16 \pm 0,05$ & $*$ \\
\hline
\end{tabular}

The data shown in Table 7 is related to the difference among Cabernet sauvignon, Pinot noir and Nebbiolo varieties according to their berry skin and seed hardness parameters. In both 2004 and 2005 there is a significant difference between varieties, therefore berry skin and seed break force and energy are meaningful parameters for varietal characterization and differentiation. Nebbiolo indeed was the variety with the more resistant seeds $(55,8 \mathrm{~N}$ break force in 2004 and $58,9 \mathrm{~N}$ in 2005$)$ and $(14,4 \mathrm{~mJ}$ break energy in 
2004 and $15,9 \mathrm{~mJ}$ in 2005$)$, but with the less resistant berry skins $(0,46 \mathrm{~N}$ break force in 2004 and $0,35 \mathrm{~N}$ in 2005$)$ and $(0,34 \mathrm{~mJ}$ in 2004 and $0,18 \mathrm{~mJ}$ in 2005). In opposition, Pinot noir had the weakest seeds but the toughest berry skins. Cabernet sauvignon showed a medium hardness for berry skins and seeds.

The high berry skin hardness of Pinot noir could be due to a reduced level of maturity compared to the other two varieties with low sugar content $(20,3 \%$ Brix) and high acidity $7,6 \mathrm{~g} / \mathrm{L}$ tartaric acid in 2004 and $6.8 \mathrm{~g} / \mathrm{L}$ tartaric acid in 2005 , since the berry skin hardness decreases when sugars increase (Lee and Bourne, 1980). It could likewise be the consequence of high berry skin thickness (Rolle et al., 2006b). Berry skin resistance to rupture (splitting) is nevertheless important from the agronomical and phytopathological point of view (Considine, 1981; Lang e During, 1990; Bišof et al., 1994), as well as from the technological point of view, as this characteristic could reduce cell permeability (Cagnasso et al., 2005).

Coombe (1973) reported that the growth of the grape berry is characterized by two successive sigmoid curves, with a plateau in between that corresponds to three stages of development. During stage I, the pericarp and seed cell numbers increase. During this stage the seed approaches its full size. During stage II, the seed embryo develops with a concomitant hardening of the seed coat (Coombe, 1960). Stage III is the ripening stage when sugars rapidly accumulate. The inception of stage III (termed véraison) is characterized by berry softening. By véraison, much of the seed is fully developed but during the third and last grape ripening stage, the seeds mature, turn from green to brown and become hard and desiccated. The high seed hardness of Nebbiolo is therefore an indication of mature seeds whereas the low seed hardness level of Pinot noir could be due to an uncompleted third ripening stage. Therefore such aspect needs to be subsequently investigated.

Table 7 Cabernet sauvignon, Pinot noir and Nebbiolo berry skin and seeds hardness. Sign $=$ significance $* * * p<0.001, * * p<0.01, * p<0.05$, ns $=$ not significant. (Inside the cells, the significance of the difference among the vineyards is reported).

\begin{tabular}{ccccccccc}
\hline & \multicolumn{9}{c}{2004} & \multicolumn{7}{c}{2005} \\
\cline { 2 - 8 } & Fsk & Wsk & Fs $(\mathrm{N})$ & $\begin{array}{c}\text { Ws } \\
(\mathrm{mJ})\end{array}$ & Fsk $(\mathrm{N})$ & $\begin{array}{c}\text { Wsk } \\
(\mathrm{mJ})\end{array}$ & Fs $(\mathrm{N})$ & Ws $(\mathrm{mJ})$ \\
\hline Cabernet & $0,51 \pm$ & $0,35 \pm$ & $44,5 \pm$ & $12,21 \pm$ & $0,46 \pm$ & $0,23 \pm$ & $43,4 \pm$ & $11,61 \pm$ \\
sauvignon & 0,07 & 0,13 & 6,94 & 3,50 & 0,05 & 0,06 & 5,44 & 2,42 \\
& $*$ & $* * *$ & $\mathrm{~ns}$ & $\mathrm{~ns}$ & $\mathrm{~ns}$ & $\mathrm{~ns}$ & $\mathrm{~ns}$ & $\mathrm{~ns}$ \\
& $0,57 \pm$ & $0,35 \pm$ & $35,9 \pm$ & $11,06 \pm$ & $0,50 \pm$ & $0,27 \pm$ & $41,3 \pm$ & $11,65 \pm$ \\
Pinot noir & 0,12 & 0,12 & 7,00 & 3,75 & 0,07 & 0,06 & 8,37 & 3,19 \\
& $* * *$ & $\mathrm{~ns}$ & $*$ & $\mathrm{~ns}$ & $\mathrm{~ns}$ & $\mathrm{~ns}$ & $\mathrm{~ns}$ & $\mathrm{~ns}$ \\
Nebbiolo & $0,46 \pm$ & $0,34 \pm$ & $55,8 \pm$ & $14,45 \pm$ & $0,35 \pm$ & $0,18 \pm$ & $58,9 \pm$ & $15,91 \pm$ \\
& 0,09 & 0,13 & 10,66 & 5,00 & 0,06 & 0,05 & 10,34 & 4,36 \\
Sign & $\mathrm{ns}$ & $\mathrm{ns}$ & $\mathrm{ns}$ & $*$ & $\mathrm{~ns}$ & $\mathrm{~ns}$ & $\mathrm{Ns}$ & $\mathrm{ns}$ \\
& $* * *$ & $\mathrm{~ns}$ & $* * *$ & $* * *$ & $* * *$ & $* * *$ & $* * *$ & $* * *$ \\
\hline
\end{tabular}

\section{Conclusions}

Texture analysis proved to be an efficient method for the assessment of wine grape mechanical behavior. The experiment showed a high discrimination between Cabernet sauvignon, Pinot noir and Nebbiolo grapes. The knowledge of texture indices could provide important qualitative information for the 
oenologist during the planning and management of the pressing and maceration processes.

In order to acquire wider information it becomes necessary to extend the study to check the possible correlations between data obtained by texture analysis and grape chemical parameters, with a particular emphasis in those related to phenolic maturity, which in the past involved long and expensive methodologies.

Finally, it is interesting to establish some texture analysis tests that are able to integrate human sensorial capacities in addition to furnishing objective evaluations of the mechanical parameters required in some grape sensory analysis cards.

\section{References}

Abbal P., Boulet J.C., Moutounet M. 1992. Utilisation de parametres physiques pour la caratérisation de la véraison des baies de raisin. Journal International de la Science de la Vigne et du Vin, 26, 231-237.

Bernstein Z., Lustig, I. 1981. A new method of firmness measurement of grape berries and other juicy fruits. Vitis, 20, 15-21.

Bišof R., Kozina B., Vicic M. 1994. Resistance of Italian Riesling (Vitis vinifera L.) berries to breaking off and pressure. Current problems in agricultural engineering. 291-299.

Borsa D., Gentilizi N., Di Stefano R., Ummarino I., Follis R. 2002. Evoluzione della composizione polifenolica di uve da cultivars diverse durante la maturazione. L'Enologo, 38, 10, 81-98.

Bourne M. C. 2002. Food Texture and Viscosity: Concept and Measurement. Second Ed., Academic Press, New York.

Cagnasso E., Caudana A., Rolle L., Gerbi V. 2003. Contributo allo studio della maturità fenolica in uve piemontesi. Quad. della Scuola di Specializzazione in Scienze Viticole ed Enologiche, 26, 61-80.

Cagnasso E., Caudana A., Rolle L., Gerbi V. 2005. Profili di maturazione e scelta di vinificazione per la valorizzazione varietale. Informatore Agrario Supplemento $\mathrm{n}^{\circ} 1$ to $\mathrm{n}^{\circ} 14,23-26$.

Cayla, L., Cottereau, P., Renard, R. 2002. Estimation de la maturité phénolique des raisins rouges par la méthode I.T.V. standard. Revue Française d'Oenologie, 193, 10-16.

Cheynier V. 2001. Grape polyphenols and their reactions in wine. Polyphenols Acualités, 21, 4-11.

Coombe B.G. 1960. Relationships of growth and development to changes in sugars, auxins, and giberellins in fruit of seeded and seedless varieties of Vitis vinifera. Plant Physiol., 35 (2), 241-250.

Coombe B.G. 1973. The regulation of set and development of the grape berry. Acta Hortic., 34, 261-273.

Considine J.A. 1981. Correlation of resistance to physical stress with fruit structure in the grapes Vitis vinifera L. Australian journal of Botany,29, 4, $475-482$.

Crespy A. 2002. La maturité polyphénolique. Revue Française d'Oenologie, 105,40 .

Failla O., Brancadoro L., Scienza A. 2005. Maturazione, maturità e qualità dell'uva. L'Informatore Agrario. Supplemento al N.1 al N. 14, 7-13. 
Gerbi V., Rolle L., Guidoni S., Zeppa G., Schneider A. 2003. Indagine sul profilo antocianico di vitigni autoctoni piemontesi. In: Ricerche e innovazioni nell'industria alimentare, Vol. VI, p. 377. Chirotti Editore, Pinerolo.

Glories Y., Augustin M. 1993. Maturité phénolique du raisin, consèquences technologiques : applications aux millésimes 1991 et 1992. Actes du Colloque "Journée technique du CIVB" 21 Janvier, Bordeaux, 56.

Grotte M., Cadot Y., Poussier A., Loonis D., Piétri E., Duprat F., Barbeau G. 2001. Determination du degré de maturité des baies de raisin par des mesures physiques: aspects méthodologiques. Journal International de la Science de la Vigne et du Vin, 35, 87-98.

Lang, A., During, H. 1990. Grape berry splitting and some mechanical properties of the skin. Vitis, 29, 61-70.

Laszlo J,C., Saayman D. 1991. Optimum harvesting stages for Dan-benHannah, La Rochelle and bonheur table grape cultivar. Deciduos Fruit Grower, 41, 257-263.

Lee C. Y., Bourne M.C. 1980. Changes in grape firmness during maturation. Journal of Texture Studies, 11, 2, 163-171.

Liang M., Chen L. H., Hegwood C.P. 1990. Physical and mechanical properties of muscadine grapes related to maturity, mechanical harvesting and processing. American Society of Agricultural Engineers, 90-6548, 32.

Martinez L. 2002. La dégustation des baies de raisin. Revue des Oenologues, 29, 105, 19-21.

Mattivi F., Prast A., Nicolini G., Valenti L. 2003. Il potenziale polifenolico delle uve rosse e la sua applicazione in enologia. L'Enologo 10, 105-114.

Mencarelli F., Massantini R., Lanzarotta L., Botondi R. 1994. Accurate detection of firmness and colour changes in the packing of table grapes with paper dividers. Journal of Horticoltural Science. 69, 2, 299-304.

Moutounet M., Rigaud J., Souquet J.M., Cheynier V. 1996. Caractérisation structurale des tanins de la baie du raisen. Bulletin de l'O.I.V., 69 (783-784), 433-443.

Robin, J.P., Abbal, P., Flanzy C. 1996. La fermeté des baies de raisin: définition d'un indice de fermeté corrélation avec les modofications de couleur et application à la détection précoce de la véraison. $\mathrm{V}^{\mathrm{e}} \mathrm{S} y m p$. Int. Enol., bordeaux 15-17 juin 1995, Coordonnateur A. Lonvaud-Funel, Ed. Technique et Documentation, Londres, Paris, New-York, 109-114.

Robin, J.P., Abbal, P., Salmon J.M. 1997. Fermeté et maturation du raisin. Définition et évolution de différents paramètres rhéologiques au cours de la maturation. Journal International des Sciences de la Vigne et du Vin, 31, 127-138.

Rolle L., Ghirardello D. Zeppa G., Gerbi V. 2006. Applicazione della Texture Analysis alla valutazione della qualità dell'uva. Quad. Vitic. Enol. Univ. Torino, 28. (in press).

Rolle L., Letaief H., Zeppa G., Gerbi V. 2006b. Texture characteristics appraisal of mountainous Nebbiolo grapes. Actes Premier Congrès International sur la viticulture de montagne et en forte pende, Italie, SaintVincent (AO), 17-18 Marzo, P79-80, T1-P-10.

Rousseau J., Delteil D. 2000. Présentation d'une méthode d'analyse sensorielle des raisins. Principe, méthode et grille d'interprétation. Revue Française d'Oenologie, 183, 10-13. 
Rousseau J. 2001. Suivi de la maturité des raisins par analyse sensorielle descriptive quantifiée des baies. Relation avec les profils sensoriels des vins et les attentes des consommateurs. Bulletin de l'O.I.V., 74 (849-850), 719 728.

Ruiz Hernandez M. 1996. Estudios of berry skin structure of red Vitis vinifera grapes from Rioja. Semana Vitivinicola, 2579, 91-93.

Saint-Crique N., Vivas N., Glories Y. 1998a. Apports récents à 1'interprétation des critères de la qualité des vin rouges. Revue Française d'Oenologie, 169, 19-21, 24-25.

Saint-Criq N., Vivas N., Glories Y. 1998b. Maturation phénolique des raisins rouges relation avec la qualité des vins. Comparaison des cépges Merlot et Tempranillo. Progrès Agricole et Viticole, 115 (13-14), 306-318.

Saint-Criq N., Vivas N., Glories Y. 1998c. Maturité phénolique : définition et contrôle. Revue Française d'Oenologie, 173, 22-25.

Sato, A., Yamane, H. Hirakawa, N. , Otobe, K., Yamada, M. 1997. Varietals differences in the texture of grape berries measured by penetration tests. Vitis, 36, 7-10.

Sato, A., Yamada M. 2003. Berry texture of table, wine, and dual-purpose grape cultivar quantified. HortScience,38, 4, 578-581.

Sims C.A., Halbrooks M.C. 1986. Quality comparison of "Orlando Seedless" with "Thompson Seedless" grapes. Proceedings of the Florida State Horticultural Society, 99, 193-194.

Uys D.C. 1996. Firmness meter for grape berries: how firm are our table grapes really?. Deciduous Fruit Grower, 46, 379-383.

Vargas A., Perez J., Zoffoli J.P., Perez A. 2001. Evolucion de la textura de bayas de uva del cv. Thompson seedless. Cien. Investig. Agr. 27, 2, 117-126.

Venencie C., Uveira M.N., Guiet S. 1997. Maturité polyphénolique du raisin mise en place d'une méthode d'analyse de routine. Revue Française d'Oenologie, 167, 36-37, 40-41. 